\title{
12. ÖRÖKNAPTÁR AZ OKLÁNDI UNITÁRIUS TEMPLOM MENNYEZETI KAZETTÁINAK EGYÜTTESÉBEN
}

A homoródoklándi unitárius templom a 13. század második felében épült, és freskókkal díszített Árpád-kori építmény lehetett egykor. Az eltelt évszázadok alatt azonban olyan átépítéseken, javításokon ment keresztül, amelyek során eredeti jellegét és formáját elveszítette. Azonban - mintegy kárpótlásként az elpusztult részekért - olyan szépen festett mennyezetekkel gyarapodott, amelyek a 18. századi magyar deszkamenynyezet-festés szép és minőségi emlékei.
A templomhajó kazettás mennyezetét 1771-ben festette Elekes András oklándi festőasztalos. Ha figyelmesen szemügyre veszszük ennek a $8 \times 9$ kazettából álló mennyezetnek a motívumvilágát, a növény és virágornamentikát, valamint az ezeket kiegészítő állatalakokat, akkor a stílus és formák alapján egy önfeledten és szabadon festő művészi alkatra következtethetünk. Erre egy felírat is utal, amely szerint az oklándi asztalos Elekes András ISTEN JÓINDULATTYÁBÓL festette.

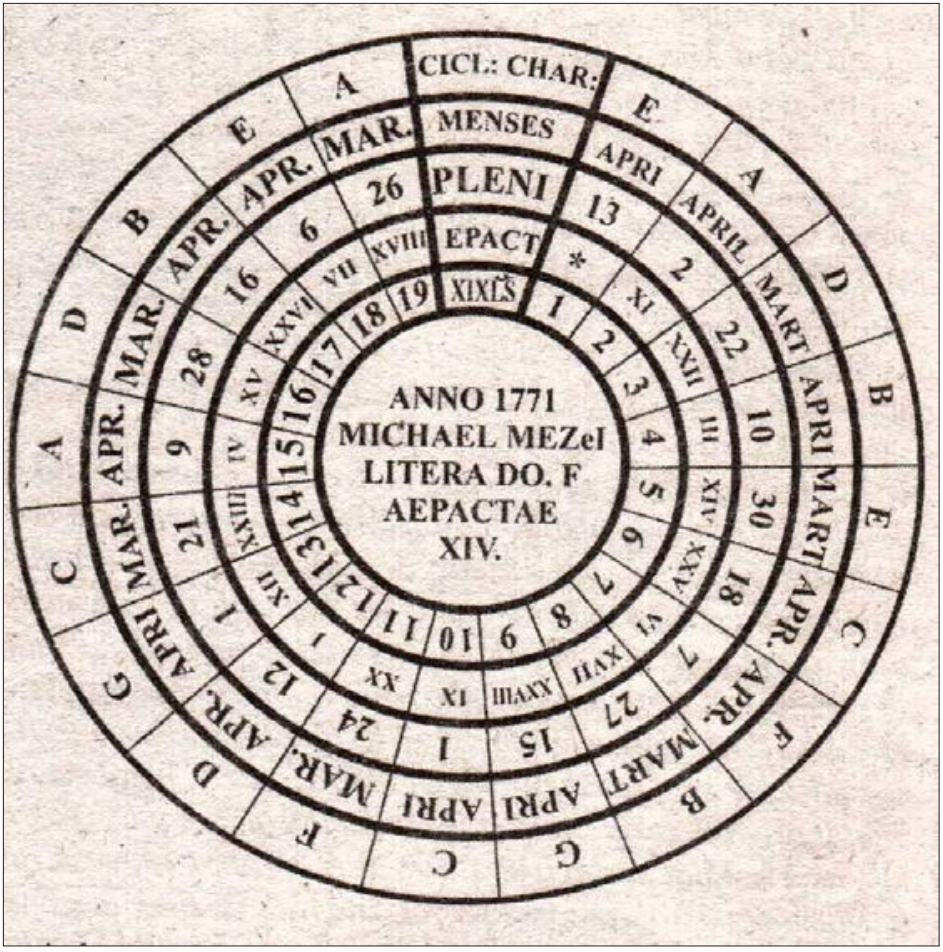

1. kép. A homoródoklándi húsvét-kazetta megszerkesztett változata 


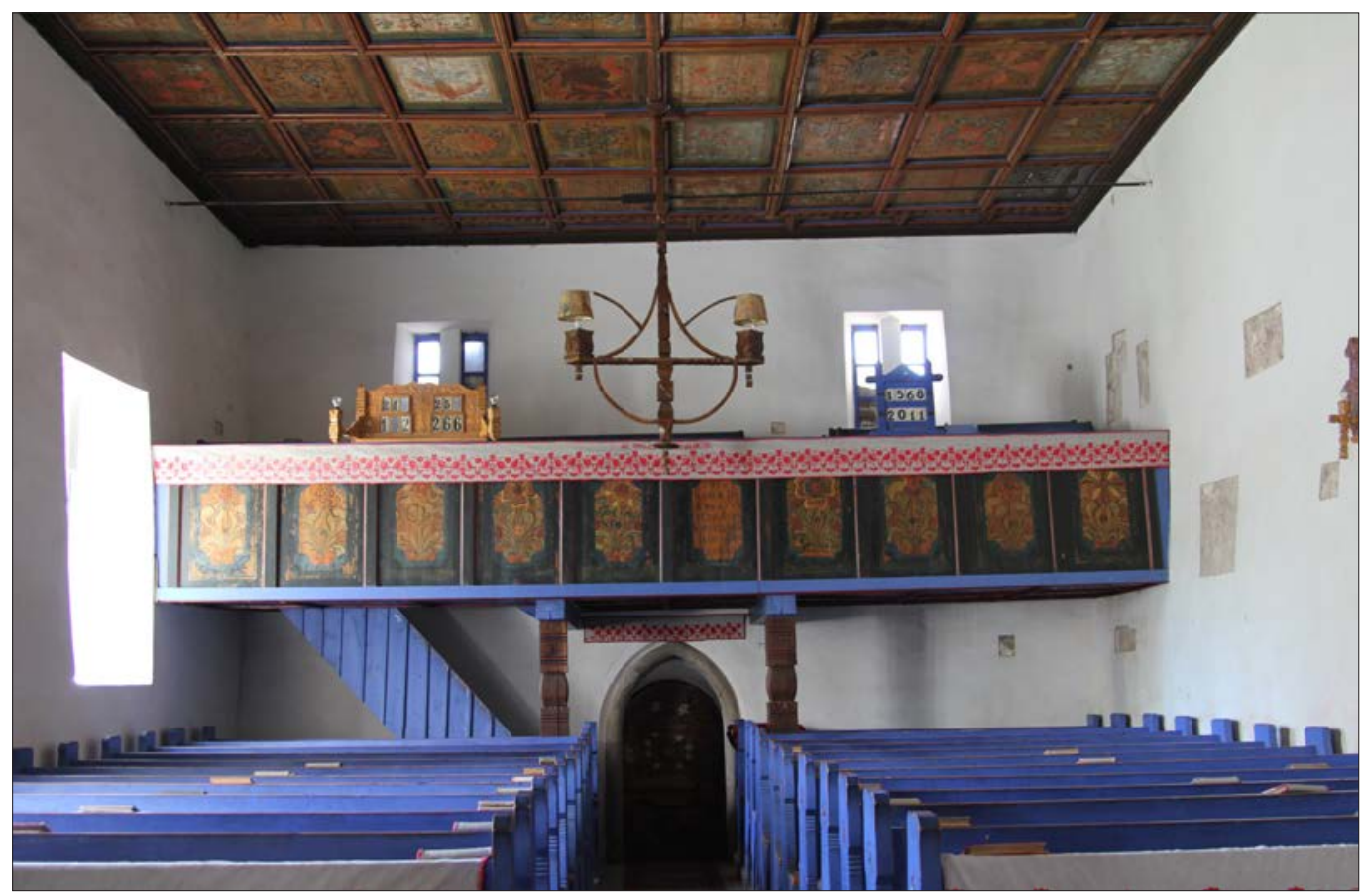

2. kép. A homoródoklándi unitárius templom kazettás mennyezete

Tovább vizsgálódva a festett kazettás mennyezeten, a templom diadalívétől számított második és harmadik sorban két olyan különös kazetta ragadja meg figyelmünket, amelyek mindenben eltérnek a többitől.

Az egyiken - a harmadik sorban - legnagyobb meglepetésünkre a SYSTEMA COPERNICANUM feliratot olvashatjuk, naprendszerünk vázlatos rajzának kíséretében (Nap, bolygók és azok holdjai), a másik kazettán - a második sorban - pedig egy koncentrikus körökből álló táblázatot láthatunk rövidítésekkel, arab és római számokkal. Azt, hogy mire szolgált egykor, nem tudjuk ma már, használata a feledés homályába merült.

\section{A kazetta leírása}

A téglalap alakú kazetta közepén 6 koncentrikus, pirossal festett kör található, amelyek értelemszerűen 5 körgyűrűt és egy köz- ponti kört határoznak meg. Minden gyürü sugárirányba húzott fekete vonallal 20 részre van felosztva, amely részek közül 19 egyforma nagyságú, míg a húszadik mérete másfélszerese a többinek. Ez utóbbi öt nagyobb részben latin szavak, rövidítések olvashatók. Ha figyelmesen szemléljük, akkor egy kör alakúra görbített táblázattal állunk szemben, ahol a nagyobb részekben a sorok megnevezése található, az egyforma gyürücikkekben pedig a megnevezéseknek megfelelő értékek. Ha a legbelső körben található szöveg fekvése alapján határozzuk meg a kazetta síkjának topográfiáját, azaz a lent és fent, illetve a jobb és bal fogalmát, akkor a kazettán a kör alakú táblázat jobb oldalán egy lentről felfelé vastagodó, S alakban kanyargó fekete kígyót találunk. Bal oldalán, erős fekete kontúrral pedig egy három hurkot formázó, önmagába visszatérő zárt szalag látható. A kazetta 
négy sarkában egy-egy fehérrel kontúrozott piros tulipáncsokor helyezkedik el, amelyek a kazetta átlói mentén többé-kevésbé szimmetrikusak.

A belső, központi körben a következő felirat áll: ANNO 1771/ MICHAEL MEZeI/ LITERA DO. F/ AEPACTAE/ XIV.

A belülről kifelé számított első gyưrű megnevezésmezejében XIX LS olvasható, az L és az $S$ betűk felett pedig egy rövid hullámos vonal. A második gyürűben az EPACT szó áll. Fölötte PLENI, a negyedik gyürüben pedig MENSES, e fölött, az ötödik külső gyürűben CICL.: CHAR. latin szavak, illetve rövidítéseik olvashatók.

A belső gyürüben 1-től 19-ig növekvő arab számok, a másodikban római számok, a harmadikban megint arab számok találhatók. A negyedik gyürűben az APRI és MART (április és március) hónapok rövidítései, a külső gyűrű minden rekeszében pedig egy-egy betû található A-tól G-ig, látszólag minden rendszer nélkül.

\section{Feltételezések és magyarázatok}

A központi körben olvasható Mezei Mihály név minden bizonnyal arra utal, hogy ezt a táblázatot ő szerkesztette. Mezei Mihályról annyit tudunk, hogy Homoródoklándon teljesített papi szolgálatot 1771 és 1777 között.

A MENSES (latinul hónapok) és a PLENI (latinul tele) gyürűkben olvasható rövidítések és értékek alapján egyfajta naptárra gondolhatunk, feltételezve azt, hogy Mezei felsőbb tanulmányokat végezve érthetett a naptárkészítéshez. Talán öröknaptár, esetleg valamilyen egyházi vagy világi esemény időpontjának meghatározására szolgáló táblázat? Ilyen és ehhez hasonló kérdések merülhetnek fel e táblázat láttán. Ezek a feltételezések aztán szertefoszlanak, ha a MENSES gyürűkben olvasható rövidítésekre koncentrálunk.
Az, hogy a hónapokat jelölő részben csak a március és április hónapok szerepelnek, arra enged következtetni, hogy húsvét napjának meghatározását szolgáló táblázattal állunk szemben. Ugyanis húsvét ünnepe, mozgó volta ellenére, mindig vagy március vagy április hónapra esik. Mindez húsvét vasárnapjának meghatározásából következik. Ennek értelmében húsvét vasárnapja a tavaszi napéjegyenlőséget követő első telehold utáni első vasárnap. Legkorábban a húsvétvasárnap akkor van, ha március 21-én telehold van, és a következő nap vasárnap, azaz március 22-én. A húsvétvasárnap legkésőbbi dátuma pedig április 25., ami akkor áll fenn, ha március 20 -án volt telehold, azaz a napéjegyenlőség előtt 1 nappal, és ennek megfelelően a következő telehold 29 nap múlva éppen vasárnapra esik. Ilyenkor a rá következő vasárnap lesz húsvét vasárnapja. Ez pedig április 25. Ha ezt a felismerést továbbgondoljuk, és a MENSES gyűrűben található számokkal vetjük egybe - feltételezve ezekről, hogy napokat jelölnek -, olyan dátumokat kapunk, amelyek mindenike március 21-e és április 18-a közé esik, beleértve a két dátumhatárt is. E két szélső érték viszont éppen azokat a napokat jelöli, amely napokon, ha telehold van, akkor húsvét vasárnapja legkorábbra, illetve legkésőbbre kerül.

Ezen felismerések alapján egyre inkább hajlunk arra, hogy a kazettában található koncentrikus körökön álló táblázat a húsvétvasárnap pontos dátumának meghatározására szolgál, szolgált.

Folytatva az előző gondolatmenetet, vizsgáljuk meg a többi gyürüben található kifejezést. XIX LS a legbelső gyűrű megnevezése. A gyưrűn számok helyezkednek el növekvő sorrendben 1-től 19-ig. Ez arra enged következtetni, hogy az úgynevezett aranyszámokkal van dolgunk. 


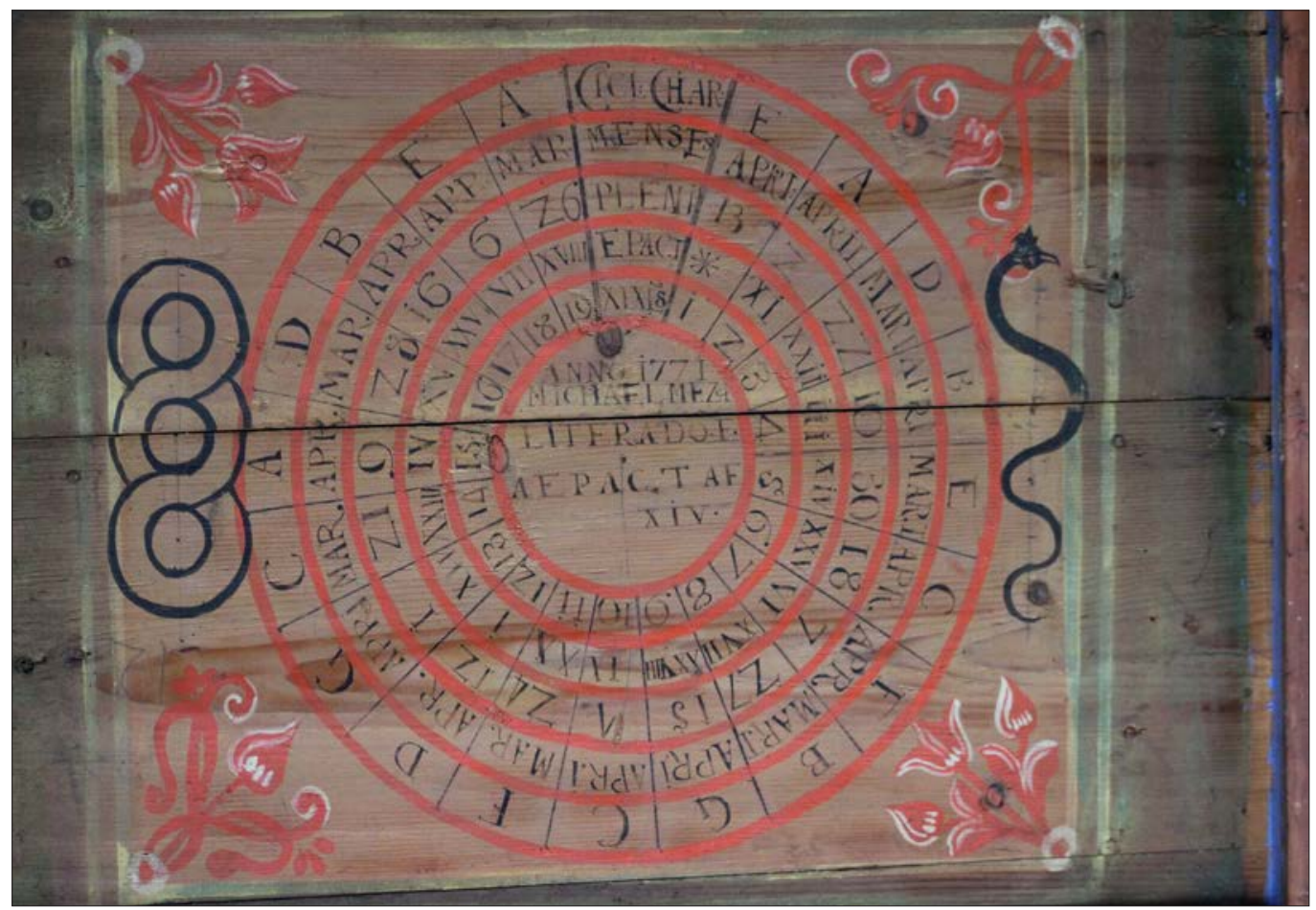

3. kép. A homoródoklándi unitárius templom kazettás mennyezetén a húsvétkazetta

Az éveket napévben számoljuk, ám a húsvét ünnepe, amint az köztudott, a hold járásához igazodik. Ezért szükséges a napévnek a holdévvel való kiegyenlítése. 19 tropikus évet követően a hold fényváltozásai az év ugyanazon napjára esnek. Ezt a 19 éves ciklust nevezik Metón-ciklusnak, amelynek segítségével a nap és a holdév közötti különbség kiegyenlítődik.

Ezt látszik megerősíteni az LS betűk fölött található kis hullámos vonal, amely mintegy jelzi a Hold, latinul L(una) és a Nap S(ol) öszszekapcsolását.

Azt, hogy egy adott év a ciklus hányadik éve, az a következő egyszerű számítás alapján határozható meg: az évszámhoz egyet adva, azt elosztjuk 19-cel, és az osztás maradéka megadja a cikluson belüli helyét az adott évnek. Mivel a húsvét kiszámítása során ennek a számnak kiemelt fontossága van, numerus aurusnak, azaz aranyszámnak nevezték el. Pl. 1771 aranyszámát a következőképpen kapjuk meg: $1771+1=1772,1772: 19=93+5$ (vagyis a maradék 5), tehát 1771 aranyszáma 5. Az EPACT, aepactae kifejezés görögül felesleget jelent, amelyet időmérésnél használnak. Vagyis az a felesleg, az az időköz, amellyel egy időpont egy korábbit, egy előzőt túlhalad. Ezt a kifejezést gyakorlatilag csak a csillagászatban, a nap- és a holdév összehasonlításánál használták, használják. Ebben az összefüggésben pedig az epakta is azt mutatja meg, hogy az év egy adott napján hány napos a Hold, azaz hány nap telt el a legutóbbi újhold óta. Még általánosabban megfogalmazva az epakta nem más, mint a nap- és holdév közötti különbség napokban kifejezve egy adott napév szerinti dátumkor. 
A húsvéttábla külső gyürüjének magyarázószövegében a CICL (ciklus) s a CHAR (karakter) fogalmak latin elnevezéseinek rövidítése olvasható. Egykor az év napjait január 1-jétől kezdve folytatólagosan 7 betűvel jelölték A-tól G-ig. Ebből azt a betűt, amely az év első vasárnapját jelölte, vasárnapbetűnek (littera Domenicalis) nevezték. Közönséges évben (nem szökőév) egész éven át ugyanaz a betú jelölte a vasárnapot. Ha pl. egy évben január elseje péntekre esett, akkor másodika szombatra és harmadika vasárnapra. Így erre az évre a vasárnap betű C. Ennek megfelelően január 10. is vasárnap, és betújele $\mathrm{C}$. Szökőév esetén a zavart, a csúszást úgy küszöbölték ki, hogy a február 24-i ún. szökőnapot és az azt követő február 25-ét ugyanazon betûvel jelölték.

A CICL (ciklus) és a CHAR (karakter) jelölés a fentiek figyelembevételével a holdciklus dátumait jelölő karaktereket, betűket jelenti. Esetünkben ezek a karakterek a telehold napjainak betűi. Segítségükkel, ha ismert az adott év vasárnapbetüje, kiszámítható pontosan, hogy holdtölte után mikor lesz vasárnap.

A húsvétkazettán található felíratok tisztázása után és az azok között fellelhető öszszefüggések vizsgálata során megállapítható, hogy egy olyan különleges húsvétkazettával van dolgunk, amelynek az volt, az lehetett a célja, hogy bizonyos ismeretek birtokában segítsen előre megállapítani egy adott évben húsvét vasárnapját.

\section{A húsvétkazetta használata}

1. Próbálkozzunk a kazettán olvasható évszámmal 1771. Leghamarabb az év aranyszámát számítsuk ki. Ezt az (1771+1)/19 osztásból származó maradék egész szám adja, ami 5, mert ha az 1772-t elosztjuk 19-cel, akkor 93-at kapunk, a maradék pedig 5. Az 5-ös szám 1771 aranyszáma. A húsvétkazettán a belső körön megkeressük az 5-ös számot, és sugárirányba, kifelé leolvassuk a harmadik gyưrüben (PLENI) található értéket, ami 30, a fölötte levő 4-ik (MENSES) gyűrűben pedig a MART kifejezést. Vagyis a belső gyűrűben található 5-ös számra épülő oszlopból kiolvashatjuk a MENSE MART és a PLENI 30 értékeket. Ez azt jelenti, hogy március 30án volt telehold 1771-ben. Az adott oszlop legfelső mezejében, azaz az 5-ik gyűrűben $\mathrm{E}$ betű olvasható. Feltételezzük, hogy az E betû ez esetben a telehold napjának betűjele.

Azt, hogy az 1771-es évnek melyik volt a vasárnapbetűje, ma különböző szakkönyvekből hamar megállapíthatjuk. Egykor egy adott év vasárnapbetújének ismerete teljesen természetes és általános volt az írni és olvasni tudók körében. Ám ha véletlenül valamiért nem tudták, akkor egyszerű viszszaszámítással meg tudták határozni, hogy január elseje milyen napra esett, és ennek függvényében meghatározhatták a vasárnapbetűt. 1771 vasárnapbetűje F volt. A kazettáról leolvasott adatok szerint a holdtölte napja március 30., és betűje E. A vasárnapbetű pedig F, tehát 1771-ben húsvét vasárnapja március 31-én volt, mert az E-t követő első vasárnapbetü az F.

A húsvétkazetta belső körén MICHAEL MEZeI alatt a LITERA DO. F most már értelmet nyer, és a rövidítés feloldható ilyenformán: LITERA DOMENICA F-nek a megadásával Mezei Mihály mintegy megadja a naptárhasználat kulcsát.

2. Ellenőrzésként próbáljuk meghatározni azt, hogy mikorra esett húsvét vasárnapja 1786-ban. Ez fontos dátum lehetett az oklándi gyülekezet életében, mert a szentély menynyezetén látható kazettákat ekkor festették. Ezt a következő felirat jelzi: KÉSZITTETETT SZOLGA GYÖRGY CURATORSÁGÁBAN NA- 
GYOBB ÉS KISSEBB ELEKES ANDRÁS ÁLTAL 1786 PÜNKÖST HAVÁBAN.

1786 ARANYSZÁMA 1, $(1786$ + 1) : $19=94$ + 1. A belső gyürű 1-es oszlopából leolvasható PLENI: 13, MENSE: APRI, CHAR: E. Vagyis 1786-ban holdtölte április 13-án volt, mely napnak a betűje E. Az 1786. év vasárnapbetűje A volt, vagyis az év első napja, január elseje vasárnapra esett. A kazettán olvasható E után A betűs nap három nap múlva következik. Vagyis a holdtölte után három nap múlva lesz leghamarabb vasárnap. Tehát húsvét vasárnapja 1786-ban az április 13-át követő harmadik napra, azaz április 16-ára esett.

\section{A Julianus-naptár szerinti húsvét- számítás}

Felmerül a kérdés, hogy mi szükség van a második, EPACT elnevezésű gyűrüre, illetve az abban található római számokkal jelzett értékre. Bármilyen formában és bármilyen szabály szerint igyekeztem bevonni a húsvét dátumának kiszámításába, vagy mint fölösleges adat szerepelt, vagy pedig rossz dátumokat eredményezett.

Az ellentmondást, számos kísérlet után, úgy sikerült feloldani, hogy nem a Gergely-, hanem a Julianus-naptárra jellemző dátumok szerint végeztem a számításokat. Az epaktákat mindig valamilyen nevezetes dátumhoz kötik, adják meg, amit az epakta székhelyének vagy epacta sedesnek neveznek. A középkorban az epakta székhelye a lehetséges legkorábbi húsvétvasárnap dátumának napján, azaz március 22-én volt. Az egyház, hogy könnyítsen a számítás menetén, mindig a 14 napos holdat, a luna XIV-et vette alapul. Esetünkben a központi körben olvasható szöveg, az AEPACTAE XIV-is erre hívja fel a figyelmet.

Vagyis ha tudjuk az adott év epaktáját, akkor abból kiszámíthatjuk, hány nap kell még ahhoz, hogy a Hold 14 napos legyen, vagyis telehold.

A Julianus-naptár esetében csak 19 epakta volt lehetséges, és ezek változatlanok voltak az évszázadok során, minek következtében az újholdak az egyes hónapokban csak 19 napra esnek, a többi napokon soha nincs újhold. (Mindez természetesen csak akkor érvényes, ha figyelembe veszik azokat a korrekciókat, amelyeket általában 100 évenként hajtanak végre, és arra hívatottak, hogy a nap- és a holdfázisok között fellépő különbségeket kiegyenlítsék. Ezek az ún. holdegyenlítések, illetve napegyenlítések.) A Gergely-naptár bevezetésével az új, ún. Lilius-epakták léptek érvénybe 1582-től kezdve. Ezeknek az új epaktáknak székhelye már január 1.

Megvizsgálva a homoródoklándi húsvétkazettán szereplő epaktákat, azt állapíthatjuk meg, hogy ezek a Julianus-naptárnál használt epakták kiigazított változatai, amelyek 1700-tól 1899-ig érvényesek.

Ezek ismeretében adódik az a felismerés, hogy az oklándi húsvétkazetta a Julianus-naptár szerinti húsvét dátumnak a megállapítására is szolgál. E számítás menete a következő:

Ha ismerték az adott év epaktáját, akkor annak segítségével már könnyen ki tudták számítani a húsvéthatárt, pontosabban azt a napot, amikor telehold van. Vagyis ha tudjuk az adott év epaktáját, akkor abból kiszámíthatjuk, hány nap kell még ahhoz, hogy a Hold 14 napos legyen.

Bármilyen meglepő, ha a Julianus-naptár szerint keressük a húsvétvasárnap dátumát, akkor az oklándi húsvéttáblán feltüntetett epakták segítségével egyszerúen és pontosan meghatározhatjuk azt. Az eljárás a következő: az adott évnek megkeressük az aranyszámát, és leolvassuk a fölötte található epakta értékét. Ez az érték megadja, 
hogy március 22-én hány napos a Hold. Ha az érték 14 alatt van, akkor március 22-höz hozzáadunk annyi napot, amennyivel az adott érték kevesebb, mint 14. Ha az epakta értéke nagyobb, mint 14, akkor március 22 höz annyi napot adunk, amennyi az újhold megjelenéséhez kell, majd ehhez a dátumhoz adunk hozzá 14 napot. Ezt a gyakorlatban egyszerúen úgy számították ki, hogy a leolvasott epaktaértéket kivonták 30-ból vagy 31-ből. (Hogy melyik számot használjuk, az attól függ, hogy újhold melyik hónapra esik. Ha az újhold márciusra esik, akkor 31, ha pedig áprilisra, akkor 30.) Táblázatból vagy a mindennapi életből könnyen ki lehet számítani az adott nap betújét, és ha ismert volt az adott év vasárnapbetűje, akkor könnyen meg lehetett határozni a húsvét dátumát. Példák:

1. 1771-ben a Julianus-naptár szerint a húsvét napját a következőképpen határozhatjuk meg: az év aranyszáma 5. Az ennek megfelelő epakta érték 14, ami azt jelenti, hogy éppen március 22-én 14 napos a Hold. A Julianus-naptár szerint 1771. március 22-ének betűjele D (számítások alapján), vasárnapbetűje pedig $B$ (számítások alapján). Ebből következik, hogy húsvét vasárnapja a Julianus-naptár szerint 1771-ben március 22-t követő 5. napon, azaz március 27-én volt (a Gergelynaptár szerint, amint azt az előző példából láttuk, húsvétvasárnap 1771-ben március 31-ére esett). 2. 1786 húsvét dátumának meghatározása a Julianus-naptár szerint: az év aranyszáma 1. Az epakta értéke * (a nulla, a semmi jele), vagyis újhold. Ennek értelmében luna XIV (a tizennégy napos Hold ) tizennégy nap múlva lesz. Tehát március $22+14$ nap $=$ április 5. Április 5-ének betűje D (számítások alapján), 1786 vasárnapbetúje pedig D (számítások alapján). Ekkor az a szabály érvényesül, hogy ha a holdtölte napja vasárnapra esik, akkor a húsvétvasárnapja a következő vasárnap lesz. Tehát a Julianus-naptár szerint 1786-ban április 5-én volt a tavaszi napéjegyenlőséget követő első holdtölte. Mivel ez éppen vasárnapra esett, a húsvétszámítás szabályainak értelmében húsvét vasárnapja 7 nappal későbbre került, azaz április 12-re.

A homoródoklándi húsvétkazettán található adatokból az derül ki, hogy csak 200 évig lehetett pontosan használni, 1700-tól 1899-ig. Alkotójáról, szerkesztőjéről, Mezei Mihály unitárius papról csak annyit tudunk, hogy 1771 és 1777 között a faluban teljesített papi szolgálatot. Nem tudjuk azt sem, hogy honnan jött, és mi lett vele az Oklándon töltött szolgálat után. Mint ahogy azt sem tudjuk, hogy milyen meggondolásból helyezte el a húsvétkazettát a templomhajó mennyezetén.

Csak fokozódó csodálattal és tisztelettel gondolhatunk Mezei Mihályra, az egykori titokzatos unitárius papra, aki egy olyan táblázatot szerkesztett, amely nemcsak a Gergely-, hanem a Julianus-naptárt használók számára is lehetővé tette a legfontosabb keresztény ünnep dátumának meghatározását.

Anélkül, hogy önmagunk becsülésén és lelkiismeretén csorbát ejtenénk, biztosan és büszkén állíthatjuk, hogy a homoródoklándi unitárius templomban található húsvétkazetta az erdélyi magyar művelődéstörténet jelentős és fontos emlékeinek egyike. 